\title{
Expedition 302 summary ${ }^{1}$
}

\author{
Expedition 302 Scientists $^{2}$
}

\section{Chapter contents}

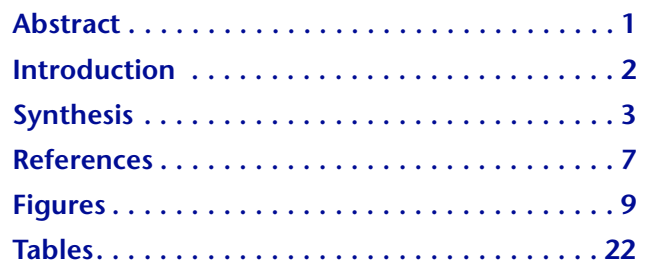

${ }^{1}$ Expedition 302 Scientists, 2006. Expedition 302 summary. In Backman, J., Moran, K., Mclnroy, D.B., Mayer, L.A., and the Expedition 302 Scientists. Proc. IODP, 302: Edinburgh (Integrated Ocean Drilling Program Management International, Inc.). doi:10.2204/

iodp.proc.302.101.2006

'Expedition 302 Scientists' addresses.

\section{Abstract}

The first scientific drilling expedition to the central Arctic Ocean was completed in September 2004. Integrated Ocean Drilling Program Expedition 302, Arctic Coring Expedition (ACEX), recovered sediment cores to 428 meters below seafloor (mbsf) in water depths of $\sim 1300 \mathrm{~m}, 250 \mathrm{~km}$ from the North Pole.

Expedition 302's destination was the Lomonosov Ridge, hypothesized to be a sliver of continental crust that broke away from the Eurasian plate at $\sim 56 \mathrm{Ma}$. As the ridge moved northward and subsided, marine sedimentation occurred and continues to the present, resulting in what was anticipated from seismic data to be a continuous paleoceanographic record. The elevation of the ridge above the surrounding abyssal plains $(\sim 3 \mathrm{~km})$ ensured that sediments atop the ridge were free of turbidites. The primary scientific objective of Expedition 302 was to continuously recover this sediment record and to sample the underlying sedimentary bedrock by drilling and coring from a stationary drillship.

The biggest challenge during Expedition 302 was maintaining the drillship's location while drilling and coring in $2-4 \mathrm{~m}$ thick sea ice that moved at speeds approaching $0.5 \mathrm{kt}$. Sea-ice cover over the Lomonosov Ridge moves with one of the two major Arctic sea-ice circulation systems, the Transpolar Drift, and responds locally to wind, tides, and currents. Until now, the high Arctic Ocean Basin, known as "mare incognitum" within the scientific community, had never before been deeply cored because of these challenging sea-ice conditions.

Initial results reveal that biogenic carbonate is present only in the Holocene-Pleistocene interval. The upper 198 mbsf represents a relatively high sedimentation rate record of the past $18 \mathrm{~m} . \mathrm{y}$. and is composed of sediment with ice-rafted debris and dropstones, suggesting that ice-covered conditions extended at least this far back in time. Details of the ice type (e.g., iceberg versus sea ice), timing, and characteristics (e.g., perennial versus seasonal) await further study. A hiatus occurs at 193.13 mbsf, spanning a 25 m.y. interval from the early Miocene to the middle Eocene between $\sim 18 \mathrm{Ma}$ and $43 \mathrm{Ma}$. The sediment record during the middle Eocene is of dark, organic-rich biosiliceous composition. Isolated pebbles, interpreted as ice-rafted dropstones, are present down to 239 mbsf, well into this middle Eocene interval. Around the lower/middle Eocene boundary an abundance of Azolla spp. occurs, suggesting that a fresh and/or low-salinity surface water set- 
ting dominated the region during this time period. Although predrilling predictions based on geophysical data had placed the base of the sediment column at $50 \mathrm{Ma}$, drilling revealed that the uppermost Paleocene to lowermost Eocene boundary interval, well known as the Paleocene/Eocene Thermal Maximum (PETM), was recovered. During the PETM, the temperature of the Arctic Ocean surface waters exceeded $20^{\circ} \mathrm{C}$.

Drilling during Expedition 302 also penetrated into the underlying sedimentary bedrock, revealing a shallow-water depositional environment of Late Cretaceous age.

\section{Introduction}

\section{Geological setting}

Ever since Bruce Heezen and Maurice Ewing recognized, in their 1961 paper, that the mid-ocean rift system extended from the North Atlantic into the Arctic Ocean, it has been assumed that the Lomonosov Ridge (Fig. F1) was originally a continental fragment broken off of the Eurasian continental margin. Aeromagnetic surveys of the Eurasian Basin have since mapped a remarkably clear pattern of magnetic lineations that are interpreted in terms of seafloor spreading along the Gakkel Ridge since Chron C24 (Wilson, 1963; Vogt et al., 1979; Kristoffersen, 1990). If we compensate for that motion of the seafloor, the Lomonosov Ridge is brought into juxtaposition with the Barents/Kara Sea margin in early Cenozoic reconstructions. Zircon-bearing bedrock samples from the Lomonosov Ridge at $88.9^{\circ} \mathrm{N}$ yield a latest Permian ( $250 \mathrm{Ma}$ ) age (Grantz et al., 2001 ). The only known source for zircons aged $\sim 250$ $\mathrm{Ma}$ in the circum-Arctic is in the post-tectonic syenites of northern Taymyr Peninsula and nearby islands in the Kara Sea, lending support to the tectonic model in which the ridge is interpreted to be a continental sliver that separated from the Eurasian plate.

As the Lomonosov Ridge moved away from the Eurasian plate and subsided, sedimentation on top of this continental sliver began and continues to the present, providing a $>400 \mathrm{~m}$ thick stratigraphic sequence. The elevation of the ridge above the surrounding abyssal plains $(\sim 3 \mathrm{~km})$ indicates that sediments on top of the ridge were isolated from turbidites and originate from biogenic, eolian, and/ or ice-rafted input.

Two key seismic profiles (AWI-91090 and AWI91091) were acquired across the Lomonosov Ridge in about 8/10 sea-ice cover in 1991 (Jokat et al., 1992). Near $88^{\circ} \mathrm{N}$ in $\sim 1 \mathrm{~km}$ of water, the ridge is $80 \mathrm{~km}$ wide with a $410 \mathrm{~m}$ thick section of acoustically stratified sediments that cap the ridge above a seismic unconformity (Fig. F2). Below this unconformity, sediments are present in down-faulted asymmetric halfgrabens.

Prior to Expedition 302, several dozen short cores $(<10 \mathrm{~m})$ of Pleistocene and Holocene age were collected from the central parts of the Lomonosov Ridge, indicating average sedimentation rates of $\sim 10$ $\mathrm{m} / \mathrm{m}$.y. (e.g., Gard, 1993; Jakobsson et al., 2000, 2001; Backman et al., 2004).

Almost no information was available, however, about pre-Pleistocene paleoenvironments in the central Arctic Ocean. Temperate marine conditions existed during the Late Cretaceous (Campanian-Maastrichtian) based on evidence provided by silicoflagellates and diatoms from three short T-3 and Canadian Expedition to Study the Alpha Ridge (CESAR) cores, all retrieved from the Alpha Ridge in the Amerasian Basin (see Thiede et al., 1990 and references therein). Most recently, Jenkyns et al. (2004) used the TEX86 paleothermometry method to estimate Cretaceous sea-surface temperatures of $15^{\circ} \mathrm{C}$. One $3.64 \mathrm{~m}$ long core (F1-422) containing a $1.65 \mathrm{~m}$ section containing middle Eocene diatoms and silicoflagellates provided the sole evidence for early Cenozoic marine conditions in the Arctic (Bukry, 1984; Ling, 1985).

\section{Scientific objectives}

The history of Arctic paleoceanography is so poorly known that we can look at the recovery of any material as true exploration that, by definition, increases our knowledge and understanding of this critical region. The key objective of Expedition 302 was to recover a continuous $>400 \mathrm{~m}$ thick sediment sequence including the upper part of the underlying acoustic basement (bedrock) from the crest of the Lomonosov Ridge. The overall primary scientific goal was to determine the paleoenvironmental evolution in the central Arctic Ocean during post-Paleocene times and to decipher its role in the global climate evolution. A secondary scientific goal was to acquire information about the early tectonic evolution of the Eurasian Basin.

Specific paleoceanographic objectives were to

- Determine the history of ice rafting and sea ice;

- Study local versus regional ice sheet development;

- Determine the density structure of Arctic Ocean surface waters, the nature of the North Atlantic conveyor, and the onset of northern hemisphere glaciation;

- Determine the timing and consequences of the opening of the Bering Strait; 
- Study the land-sea links and the response of the Arctic to Pliocene warm events;

- Investigate the development of the Fram Strait and deepwater exchange between the Arctic Ocean and Greenland/Iceland/Norwegian Sea; and

- Determine the history of biogenic sedimentation.

The tectonic objectives were focused on ridge evolution. Specific tectonic objectives for drilling on the Lomonosov Ridge were to

- Investigate the nature and origin of the Lomonosov Ridge by sampling the oldest rocks below the regional unconformity in order to establish the pre-Cenozoic environmental setting of the ridge and

- Study the history of rifting and the timing of tectonic events that affected the ridge.

\section{Strategy}

The biggest challenge during Expedition 302 was maintaining the drillship's location during drilling and coring in moving, heavy sea ice. Sea-ice cover over the Lomonosov Ridge moves with the Transpolar Drift (Fig. F3) and is affected by local responses to wind, tides, and currents. Prior to Expedition 302, the high Arctic Basin had never been deeply cored before because of these challenging sea-ice conditions.

Plans for this first-ever event were carefully crafted over several years and included a fleet of three icebreaker-class ships: a drilling vessel, the Vidar Viking, which remained at a fixed location and suspended over $1600 \mathrm{~m}$ of drill pipe through the water column and into the underlying sediments; a Russian nuclear icebreaker, Sovetskiy Soyuz; and the diesel-electric icebreaker Oden. The Sovetskiy Soyuz and Oden protected the Vidar Viking by breaking "upstream" floes into small bergy bits to allow the Vidar Viking to stay positioned to drill and recover the sediment cores.

This strategy proved to be successful. Planners had predicted that the fleet could maintain the drillship's station for up to 2 full days, yet the stationkeeping ability achieved went far beyond this expectation. The three ships coordinated their efforts through a central Fleet Manager, at times on a minute-tominute basis. The fleet kept the Vidar Viking on location in 9/10, multiyear ice for up to 9 days-a landmark feat that has empowered scientists to continue to explore this least known of our oceans through scientific ocean drilling for many years to come.

The Sovetskiy Soyuz conducted the first attack on oncoming heavy floes, whereas Oden was the last de- fense in protecting the drilling operation against the oncoming ice (Fig. F4). During these defensive operations, the officers on the Vidar Viking kept station by manually driving the powerful thrusters with the bow maneuvered to head into the direction of the oncoming ice. The ice management defense strategies were continuously updated with information from a full-time ice and weather forecast team onboard the Oden and the Sovetskiy Soyuz.

Coring operations were conducted by Seacore, Ltd., using a specially built drill rig for the Vidar Viking. Coring tools were provided by the British Geological Survey (BGS). Cores were collected on the Vidar Viking from five boreholes drilled to a maximum depth of 428 meters below seafloor (mbsf). A single wireline geophysical log was collected in one borehole.

The cores, collected in plastic liners, were sealed for postexpedition analyses onshore at the Integrated Ocean Drilling Program (IODP) repository in Bremen, Germany. In Bremen, the full suite of standard IODP processing methods was completed. Before they were stored, cores were analyzed for physical properties using a Geotek nondestructive multisensor core logger (MSCL) (see "Petrophysics" in the "Methods" chapter). Selected intervals were sampled to extract pore water and microbiology samples. During the expedition, core catcher samples were routinely transferred to the Oden twice a day for analyses that included micropaleontology, stratigraphy, petrophysics, chemistry, and sedimentology.

\section{Synthesis}

\section{Site overview}

Cores were recovered in five holes across three sites (Holes M0002A, M0003A, M0004A, M0004B, and M0004C) (Tables T1, T2, T3), with a total recovery of $68.4 \%$ (Fig. F5). The first hole at Site M0001 was abandoned because a bottom-hole assembly (BHA) was lost (see "Site operations" in the "Sites M0001M0004" chapter). Logging was attempted in two holes and data were collected over a $153 \mathrm{~m}$ openhole interval in Hole M0004B.

Expedition 302 sites are situated within $15.5 \mathrm{~km}$ of each other on seismic Line AWI-91090 and are interpreted as a single site because of the internally consistent seismic stratigraphy across that distance (Fig. F2). A limited amount of site-to-site correlation was conducted, based primarily on physical property data (gamma ray attenuation bulk density, magnetic susceptibility, $P$-wave velocity, and electrical resistivity) generated using the MSCL. Site correlation was also aided by lithologic descriptions and high-resolution geochemical pore water measurements of chiefly am- 
monia concentrations and alkalinity. In terms of recovered stratigraphy, the bulk of material was provided by Hole M0002A for the upper half of the 428 $\mathrm{m}$ long stratigraphic record and Hole M0004A for the lower half, with correlation made possible by a short overlap between the two holes. The other holes recovered multiple portions of the upper 20 mbsf and allowed construction of a composite depth scale and spliced record for this short interval.

\section{Scientific assessment outcomes}

The overall goal of Expedition 302 was to study Arctic paleoceanography in order to understand this region's past climate and its impact on Earth's climate during the Cenozoic, with particular emphasis on the change from the "greenhouse" world of the Eocene to the "icehouse" world of today.

The primary method was to apply a well-known and effective technique for complete core recovery: continuous piston core and extended core barrel sampling in multiple holes at one site. This technique results in a continuous stratigraphic record. This method was not applied during Expedition 302, as no sites were multiple cored (Table T1; Fig. F5). In addition, single-hole penetrations suffered from relatively low recovery. The average core recovery for all holes was $68.4 \%$; below $270 \mathrm{~m}(\sim 47 \mathrm{Ma})$ to total depth at 428 mbsf, the recovery dropped to $43.1 \%$. Unfortunately, low core recovery plagued recovery of two important Expedition 302 events: the Azolla and the Paleocene/Eocene Thermal Maximum (PETM), resulting in incomplete records for both.

The early results of Expedition 302 show that further analyses of the sediment and basement cores will contribute to five of the seven major paleoceanographic objectives and both of the tectonic objectives. The degree to which advances are made depends on the level of detail that can be extracted from the sediment record.

Generally, the lithologies anticipated in the proposal to IODP were encountered. The overall age span of the sediment section recovered was longer than predicted by a few million years. A major hiatus occurs in the section that spans the transition from the Neogene to the Paleogene. The hiatus means that paleoceanographic analyses over this missing interval cannot occur, but interpretation of the overall time and causal mechanisms will contribute significantly to furthering our understanding of the tectonic evolution and resulting depositional environment. The longer time interval will allow us to interpret the paleoclimate conditions during the PETM at an important geographic position for climate studies close to the North Pole.
Among the seven specific paleoceanographic objectives, scientific results from Expedition 302 will be used to determine the history of ice rafting and sea ice; study local (e.g., Svalbard) versus regional ice sheet development; reconstruct the density structure of surface waters, the nature of the North Atlantic conveyor, and the onset of northern hemisphere glaciation; make contributions to the investigation of the development of the Fram Strait and deepwater exchange between the Arctic Ocean and the World Ocean; and determine the history of biogenic sedimentation. The lack of a carbonate stratigraphic record precludes study of the timing and consequences of the opening of the Bering Strait. Biogenic carbonate is present only rarely and occasionally in the upper $19 \mathrm{~m}$ of the sediment column. The disappearance of carbonate occurs together with a decrease in $\mathrm{pH}$ and alkalinity, suggesting that the lack of cocolithophorids, calcareous foraminifers, and ostracodes in deeper sediments is caused by dissolution.

Expedition 302 results partially address the two tectonic objectives. The regional unconformity was penetrated but not well sampled except for a small bag sample. Fossils from this sample constrain timing of the initiation of rifting to between $80 \mathrm{Ma}$ and the oldest age of the sediment overlying the unconformity at $58 \mathrm{Ma}$.

Early results also reveal that the upper sediments hold a record of sea-ice distribution in the Arctic Ocean well into the middle Miocene. The situation is different in older, underlying cores where dark, organic-rich sediments contain abundant diatoms, ebridians, silicoflagellates, and dinoflagellate cysts, indicating a middle Eocene age and an environment partly characterized by ice-free, warmer surface ocean waters.

Abundant megaspores of the hydropterid fern Azolla are present at the lower/middle Eocene boundary, suggesting strongly reduced surface water salinity or perhaps even an episode of freshwater conditions at the surface. The sporadic and rare presence of radiolarians suggests that the Arctic's surface water salinities indeed were reduced throughout the Eocene interval that contains biosilica. Biosilica is not preserved before the upper lower Eocene. The dinoflagellate species Apectodinium augustum is abundantly present at $\sim 380 \mathrm{~m}$ in pyrite-rich mudstones, indicating that the PETM interval was partly recovered. During this thermal maximum, the Arctic Ocean experienced surface temperatures on the order of $20^{\circ} \mathrm{C}$ based on early results using TEX86 paleothermometry (Sluijs et al., submitted). 


\section{Lithostratigraphy}

The lithostratigraphy of the Lomonosov Ridge sites is described in terms of four units (Fig. F6). Recovered sediments, ranging in age from Holocene to Late Cretaceous (0-428 mbsf), are dominated by lithogenic material. With the exception of sandy lenses, the dominant siliciclastic component of all lithologic units is fine grained, ranging from clays to silty muds. Thin millimeter- to centimeter-thick layers of sand are present down to $\sim 198$ mbsf. The upper 220 mbsf comprises soft to hard silty clay with colors varying from light brown to olive-green to gray (Unit 1). Isolated pebbles are present throughout Unit 1, with the deepest pebble observed in Unit 2 (239.34 mbsf). This may indicate the presence of at least seasonal sea ice as early as the middle Eocene. A major hiatus occurs at the boundary of Subunits $1 / 5$ and $1 / 6$ at 198.13 mbsf.

Below 220 mbsf, the sediments change from biosiliceous silty clay to biosiliceous ooze encompassing an interval of $\sim 93 \mathrm{~m}$ (Unit 2). The biosiliceous sediments overlie an interval of hard silty clay to mudstone (Unit 3), which, at $\sim 410$ mbsf, rests unconformably on Campanian marine sands, sandstone, and mudstone (Unit 4). Results from geochemistry demonstrate that the top of Unit 3 (313-350 meters composite depth [mcd]) holds abundant authigenic silica altered from biogenic opal.

\section{Micropaleontology}

Prior to Expedition 302, information about microfossil content in central Arctic Ocean cores was limited to observations made in short piston and gravity cores. These cores held records of variable and discontinuous abundances of calcareous nannofossils, planktonic and benthic foraminifers, ostracodes, and dinoflagellate cysts (e.g., Aksu et al., 1988; Scott et al., 1989; Gard, 1993; Cronin et al., 1994; Ishman et al., 1996; Matthiessen et al., 2001). A single core from the Alpha Ridge contained middle Eocene diatoms and silicoflagellates (Bukry, 1984; Ling, 1985). Before Expedition 302, no accurate knowledge existed about which biostratigraphically useful microfossil groups would be encountered at depth. Therefore, expertise representing all possible microfossil groups were invited as science party members. Expedition 302 samples were also systematically analyzed for fish debris.

One of the most striking results is that biogenic carbonate is almost completely missing from the sediment with the exception of only the upper few meters. Dinoflagellate cysts provide the bulk of available biostratigraphic information.

A $23 \mathrm{~m}$ thick interval below $\sim 170$ mbsf appears to be nearly devoid of microfossils. This interval is inter- preted to be of middle Miocene age, based on magnetobiostratigraphy. Dinoflagellate cysts, diatoms, ebridians, and silicoflagellates are common to abundant in the middle Eocene section, which ends in an interval with megaspores of the freshwater hydropterid fern Azolla at the lower/middle Eocene boundary $(\sim 306 \mathrm{~m})$. Biosilica is not present prior to the late early Eocene $(\sim 320 \mathrm{~m})$.

The (sub)tropical dinoflagellate species A. augustum occurs abundantly at $\sim 380 \mathrm{~m}$, indicating that the Paleocene/Eocene boundary and the associated carbon isotope excursion interval was at least partly recovered.

Benthic foraminifers indicate that the lower Eocene through upper Paleocene sediments were deposited in shallow-marine, neritic environments.

\section{Sedimentation rates}

Biostratigraphy and magnetostratigraphy were used to construct the age model. Among the biostratigraphy, dinocysts provide the bulk of the Neogene biostratigraphic data. In the Eocene, diatoms and silicoflagellates were added to the dinocyst data set. The general structure of the biostratigraphic age-depth point distribution shows two distinct intervals, both having rates on the order of 1-2 cm/k.y. (10-20 m/ m.y.), namely a Pleistocene to middle Miocene interval and a middle Eocene to uppermost Paleocene interval.

A major hiatus separates the upper Paleocene from the underlying Campanian sediments, which presumably marks the boundary between underlying sedimentary bedrock and the overlying sediment drape on the ridge. Another major hiatus occurs at 198 mbsf, where an interval representing a major portion of the lower Miocene, the Oligocene, and the upper Eocene is missing.

\section{Petrophysics}

Petrophysical measurements performed during Expedition 302 included downhole wireline logging; nondestructive whole-core measurements of bulk density, compressional $P$-wave velocity, resistivity, natural gamma radiation, and magnetic susceptibility; and discrete measurements of shear strength, moisture and density, thermal conductivity, and color reflectance.

\section{Downhole wireline logging}

Downhole logging was completed in Hole M0004B using the Natural Gamma Ray Spectrometry Tool (NGT), Formation MicroScanner (FMS), Borehole Compensated Sonic (BHC) tool, and Scintillation Gamma Ray Tool (SGT). A 153 m open-hole and 65 
$m$ in-pipe interval was successfully logged, providing in situ measurements of $P$-wave velocity, resistivity, and natural gamma radiation through lithologic Subunits $1 / 3$ to $1 / 6$.

The caliper logs from the FMS (two per pass) provided a method for assessing the borehole condition. For much of the formation, the hole diameter was under gauge and narrowed significantly between 75 and 90 mbsf, at $155 \mathrm{mbsf}$, and again between 180 and 184 mbsf. The caliper logs indicated that the borehole conditions for the complete logged section were good and free of any washed-out materials.

\section{Multisensor core logger and discrete physical property measurements}

Downhole variations in density, $P$-wave velocity, and magnetic susceptibility highlight a number of prominent stratigraphic changes that exist at all sites and correlate well with observed seismic reflectors. The stratigraphic similarities among the sites allowed a single composite section to be constructed (Fig. F7).

Compositionally, the upper $220 \mathrm{~m}$ of sediment recovered from the Lomonosov Ridge is predominantly silty clay (Unit 1 ). The upper $\sim 20$ mcd shows first-order increases in both density and velocity that appear to arise from normal consolidation processes (Fig. F8). Throughout this interval, well-defined decimeter-scale variations in density, velocity, and susceptibility occur in phase. Below 20 mcd, a noticeable drop in the shear strength of sediments occurs, remaining low to $\sim 40 \mathrm{mcd}$, where moisture and density and MSCL measurements indicate an increase in the bulk density of sediments (Fig. F9). Large-amplitude variations in bulk density, $P$-wave velocity, and magnetic susceptibility characterize the bulk of Unit 1 sediments below $\sim 40$ mcd.

Between 70 and $100 \mathrm{mbsf}$, there is a shift away from the high-amplitude variation in magnetic susceptibility that is a characteristic feature of the sediments below 20 mbsf.

A noticeable decrease in all petrophysical properties measured on the MSCL occurs at 168 mbsf and accompanies the transition from predominantly olivegreen sediments into those characterized by a more yellowish to brown hue at the Subunit $1 / 3$ to $1 / 4$ boundary. One of the most prominent changes is a large decrease in $P$-wave velocity at $\sim 198$ mbsf, marking the transition into Subunit $1 / 6$, which is characterized as a silty clay having relatively high TOC and pyrite concentrations. At 220 mbsf, density decreases sharply from 1.7 to $1.3 \mathrm{~g} / \mathrm{cm}^{3}$ without a noticeable change in the $P$-wave velocity and is associated with the transition from the pyrite-rich silty clay unit into a biosiliceous ooze (Unit 2).
Large gaps in core recovery occur from $\sim 220$ to $\sim 350$ mbsf. An increase in density through this interval mirrors changes in the biosiliceous contribution to the matrix material. Below $\sim 370$ mbsf, spurious peaks in susceptibility $\left(>5 \times 10^{-3} \mathrm{SI}\right)$ and density $(>3$ $\mathrm{g} / \mathrm{cm}^{3}$ ) indicate the presence of dense material that is probably of diagenetic origin. The deepest cores recovered from Hole M0004A, documenting the transition through sandstone and mudstone and into basement, were too short and disturbed to be run on the MSCL.

\section{In situ temperature measurements}

In situ temperature was measured during coring operations using the BGS and Adara temperature tools. Postcruise processing is required to determine equilibrated in situ temperatures. The mudline temperature was recorded on all runs and varied between tools. A preliminary attempt to normalize the in situ measurements was made by using the average Adaradetermined mudline temperature and adjusting all in situ measurements to this baseline value. The average gradient, using four of the five measurements, is $30.5^{\circ} \mathrm{C} / \mathrm{km}$.

\section{Chemistry}

Shipboard pore water chemistry profiles suggest three geochemical processes: shallow carbonate dissolution, deep sulfate reduction, and shallow ammonium oxidation (Fig. F10).

Lithologic and micropaleontogical descriptions of sediment note a general absence of primary carbonate below $\sim 16$ mbsf, where $\mathrm{pH}$ and alkalinity drop below 7.4 and $2.5 \mathrm{mM}$, respectively. Assuming constant dissolved $\mathrm{Ca}^{2+}$, this means that pore waters near this depth are more corrosive to carbonate tests than the overlying sediment or water column. Carbonate tests may dissolve when buried in these corrosive pore waters.

The alkalinity inflection at 200 mbsf suggests chemical reactions are adding substantial amounts of $\mathrm{HCO}_{3}^{-}$at this depth without accompanying $\mathrm{H}^{+}$. The likely candidate is sulfate reduction of organic carbon:

$$
2 \mathrm{CH}_{2} \mathrm{O}(\mathrm{s})+\mathrm{SO}_{4}^{2-}(\mathrm{aq}) \rightarrow 2 \mathrm{HCO}_{3}^{-}(\mathrm{aq})+\mathrm{H}_{2} \mathrm{~S}(\mathrm{aq}) .
$$

Black sediments (Unit 2) were rapidly deposited below 200 mbsf. These sediments host abundant pyrite and lie beneath dark banded intervals that may be composed of other iron sulfide minerals. Organic matter in the black sediment, particularly at 200 mbsf, dissolved $\mathrm{SO}_{4}{ }^{2-}$. This reaction may have produced abundant $\mathrm{H}_{2} \mathrm{~S}$ in the past and, ultimately, iron sulfide minerals. 
A peak in alkalinity (at $\sim 6$ mcd) coincides with a sharp steady rise in $\mathrm{NH}_{4}{ }^{+}$. The peak in alkalinity supports the interpretation that some chemical reaction is producing $\mathrm{HCO}_{3}{ }^{-}$without accompanying $\mathrm{H}^{+}$. The $\mathrm{NH}_{4}{ }^{+}$profile further suggests that upward diffusing $\mathrm{NH}_{4}{ }^{+}$drives this reaction.

\section{Microbiology}

Sampling for microbiological analyses was conducted at fairly regular depth intervals from the surface (7 mbsf) to near basement (398 mbsf) with a notable gap between 169 and 241 mbsf. A total of 21 samples were preserved for enumeration of microorganisms to provide estimates of subsurface biomass. Nineteen samples were stored anaerobically for the purpose of shore-based cultivation studies. A subset of samples (18) was stored at $-51^{\circ} \mathrm{C}$ for deoxyribonucleic acid extraction and subsequent microbial community characterization. Finally, 10 samples were stored at $-51^{\circ} \mathrm{C}$ for lipid biomarker analysis.

\section{References}

Aksu, A.E., Mudie, P.J., Macko, S.A., and de Vernal, A., 1998. Upper Cenozoic history of the Labrador Sea, Baffin Bay, and the Arctic Ocean: a paleoclimatic and paleoceanographic summary. Paleoceanography, 5:519-538.

Backman, J., Jakobsson, M., Lovlie, R., Polyak, L., and Febo, L.A., 2004. Is the central Arctic Ocean a sediment starved basin? Quat. Sci. Rev., 23:1435-1454.

Bukry, D., 1981. Silicoflagellate stratigraphy of offshore California and Baja California, Deep Sea Drilling Project Leg 63. In Yeats, R.S., Haq, B.U., et al., Init. Repts. DSDP, 63: Washington (U.S. Govt. Printing Office), 539-557.

Bukry, D., 1984. Paleogene paleoceanography of the Arctic Ocean is constrained by the middle or late Eocene age of USGS Core Fl-422: evidence from silicoflagellates. Geology, 12:199-201.

Clark, D.L., Whitman, R.R., Morgan, K.A., and Mackay, S.D., 1980. Stratigraphy and glacial marine sediments of the Amerasian basin, central Arctic Ocean. Spec. Publ.Geol. Soc. Am., 181:1-57.

Cronin, T.M., Holtz, T.R., and Whatley, R.P., 1994. Quaternary paleoceanography of the deep Arctic Ocean based on quantitative analysis of Ostracoda. Mar. Geol., 19:305-332. doi:10.1016/0025-3227(94)90188-0

Gard, G., 1993. Late Quaternary coccoliths at the North Pole: evidence of ice-free conditions and rapid sedimentation in the central Arctic Ocean. Geology, 21:227-230. doi:10.1130/0091-

7613(1993)021<0227:LQCATN>2.3.CO;2

Grantz, A., Pease, V.L., Willard, D.A., Phillips, R.L., and Clark, D.L., 2001. Bedrock cores from $89^{\circ}$ north: implications for the geologic framework and Neogene paleoceanography of Lomonosov Ridge and a tie to the Barents shelf. Geol. Soc. Am. Bull., 113:1272-1281. doi:10.1130/0016-

7606(2001)113<1272: $\mathrm{BCFNIF>2.0.CO;2}$

Heezen, B.C., and Ewing, M., 1961. The Mid-Oceanic Ridge and its extension through the Arctic Basin. In Raasch, G. (Ed.), Geology of the Arctic: Torongo (Univ. Toronto Press), 622-642.

Ishman, S.E., Polyak, L.V., and Poore, R.Z., 1996. Expanded record of Quaternary oceanographic change: Amerasian Arctic Ocean. Geology, 24:139-142. doi:10.1130/00917613(1996)024<0139:EROQOC>2.3.CO;2

Jakobsson, M., Løvlie, R., Al-Hanbali, H., Arnold, E., Backman, J., and Mörth, M., 2000. Manganese and color cycles in Arctic Ocean sediments constrain Pleistocene chronology. Geology, 28:23-26. doi:10.1130/00917613(2000)028<0023:MACCIA>2.3.CO;2

Jakobsson, M., Løvlie, R., Arnold, E., Backman, J., Polyak, L., Knudsen, J.-O., and Musatov, E., 2001. Pleistocene stratigraphy and paleoenvironmental variation from Lomonosov Ridge sediments, central Arctic Ocean. Global Planet. Change, 31:1-22. doi:10.1016/S09218181(01)00110-2

Jenkyns, H.C., Forster, A., Schouten, S., and Damsté, J.S.S., 2004. High temperatures in the late Cretaceous Arctic Ocean. Nature (London, U. K.), 432:888-892.

Jokat, W., Uenzelmann-Neben, G., Kristoffersen, Y., and Rasmussen, T.M., 1992. Lomonosov Ridge-a doublesided continental margin. Geology, 20:887-890. doi:10.1130/00917613(1992)020<0887:LRADSC>2.3.CO;2

Kristoffersen, Y., 1990. Eurasian Basin. In Grantz, A., Johnson, L., and Sweeney, J.F. (Eds.), The Geology of North America (Vol. L): The Arctic Ocean Region. Geol. Soc. Am., 365-378.

Ling, H.Y., 1985. Early Paleogene silicoflagellates and ebridians from the Arctic Ocean. Trans. Proc. Palaeontol. Soc. Jpn, NS, 138:79-93.

Matthiessen, J., Knies, J., Nowaczyk, N.R., and Stein, R., 2001. Late Quaternary dinoflagellate cyst stratigraphy at the Eurasian continental margin, Arctic Ocean: indications for Atlantic water inflow in the past 150,000 years. Global Planet. Change, 31:65-86. doi:10.1016/ S0921-8181(01)00113-8

Scott, D.B., Mudie, P.J., Baki, V., MacKinnon, K.D., and Cole, F.E., 1989. Biostratigraphy and late Cenozoic paleoceanography of the Arctic Ocean: foraminiferal, lithostratigraphic, and isotopic evidence. Geol. Soc. Am. Bull., 101:260-277. doi:10.1130/00167606(1989)101<0260:BALCPO>2.3.CO;2

Sluijs, A., Schouten, S., Pagani, M., Woltering, M., Brinkhuis, H., Sinninghe Damsté, J.S., Dickens, G.R., Huber, M., Reichart, G.-J., Stein, R., Matthiessen, J., Lourens, M., Pedentchouk, N., Backman, J., Moran, K., and the Expedition Scientists, submitted. Subtropical Arctic Ocean temperatures during the Palaeocene-Eocene Thermal Maximum. Nature (London, U. K.).

Thiede, J., Clark, D.L., and Herman, Y., 1990. Late Mesozoic and Cenozoic paleoceanography of the northern polar oceans. In Grantz, A., Johnson, L., and Sweeney, J.F. (Eds.), The Geology of North America (Vol. L): The Arctic Ocean Region: Boulder (Geol. Soc. Am.), 427-458. 
Vogt, P.R., Taylor, P.T., Kovacs, L.C., and Johnson, G.L., 1979. Detailed aeromagnetic investigation of the Arctic basin. J. Geophys. Res., 84:1071-1089.

Wilson, J.T., 1963. Hypothesis of the Earth's behaviour. Nature (London, U. K.), 198:925-929.
Publication: 7 March 2006

MS 302-101 
Figure F1. Map of the Arctic Ocean showing the location of the Expedition 302 study area on the Lomonosov Ridge. The insert is a small-scale map showing the locations of Expedition 302 sites.

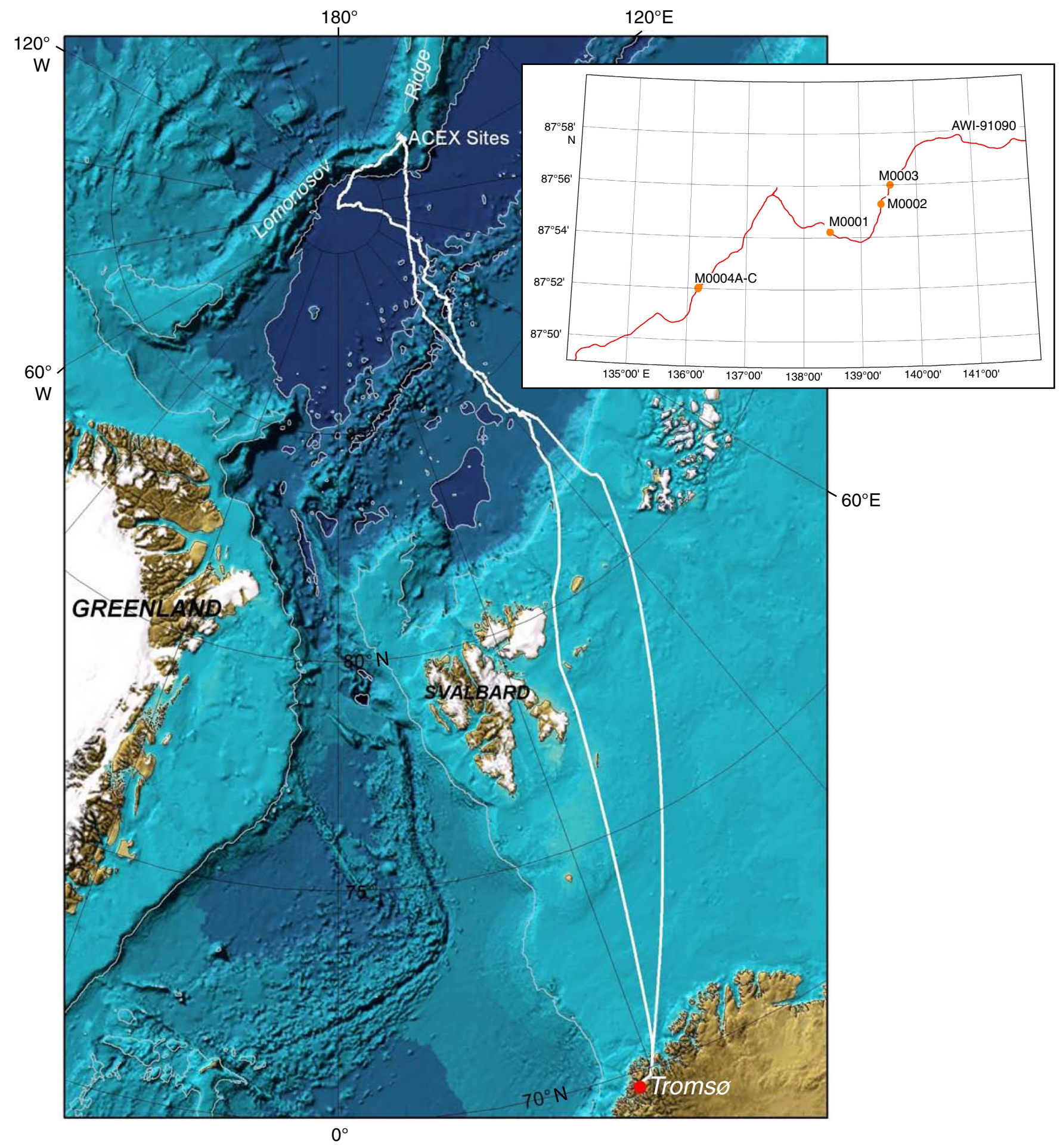


Figure F2. Seismic reflection profile of the Lomonosov Ridge (AWI-91090) with locations of Expedition 302 coring sites. Multichannel seismic data are from Jokat et al. (1992). Cores were not retrieved from Hole M0001A because the BHA (gray on figure) was lost. Hole M0004B is located $\sim 60 \mathrm{~m}$ away from Hole M0004A; Hole M0004C is located $\sim 60 \mathrm{~m}$ away from Hole M0004B. SP = shotpoint.

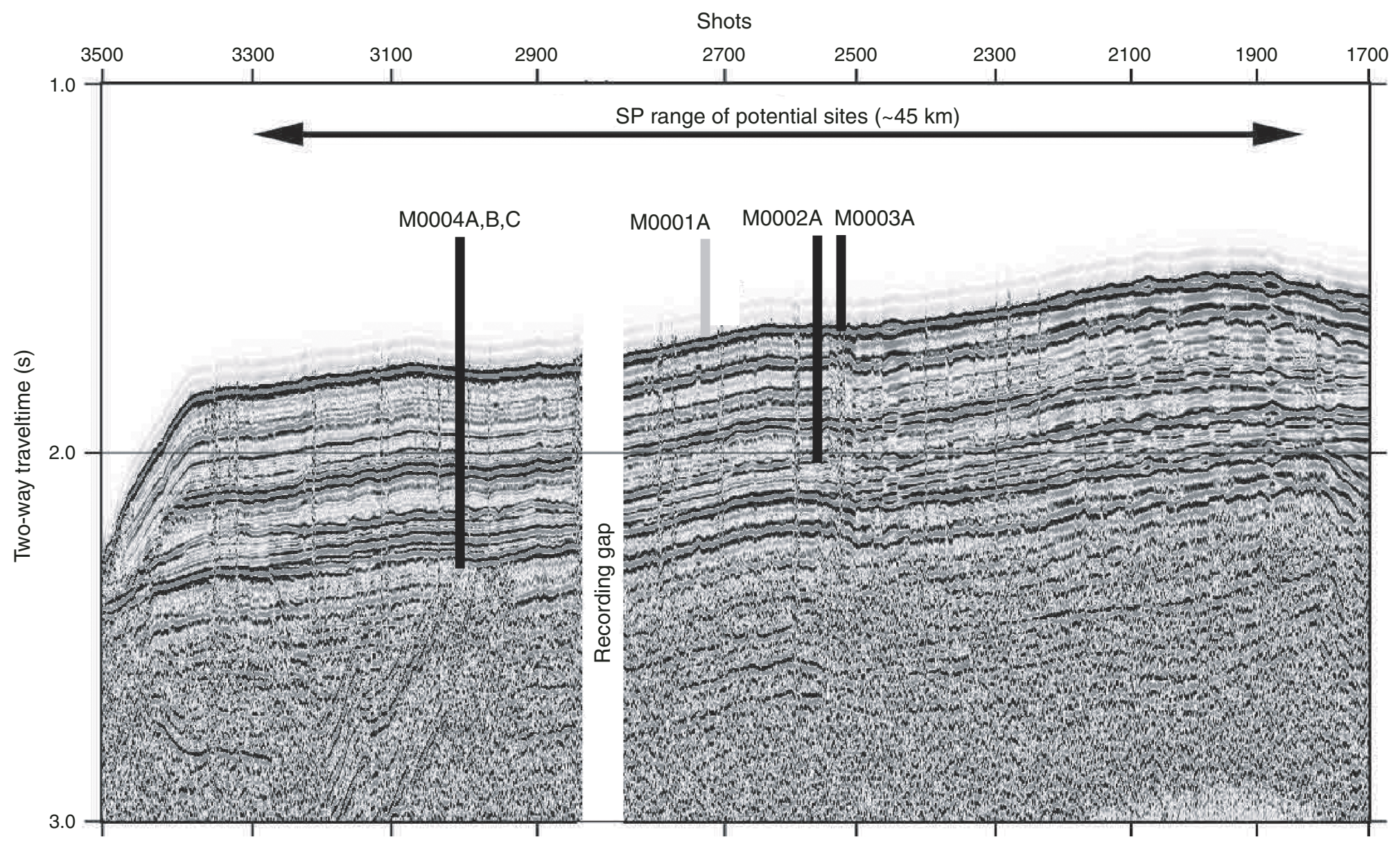


Figure F3. Generalized schematic of sea ice transport in the Arctic Ocean. Red contours denote average years of residence time before sea ice export through the Fram Strait. Arrows indicate average transport speeds (provided by Y. Kristoffersen).

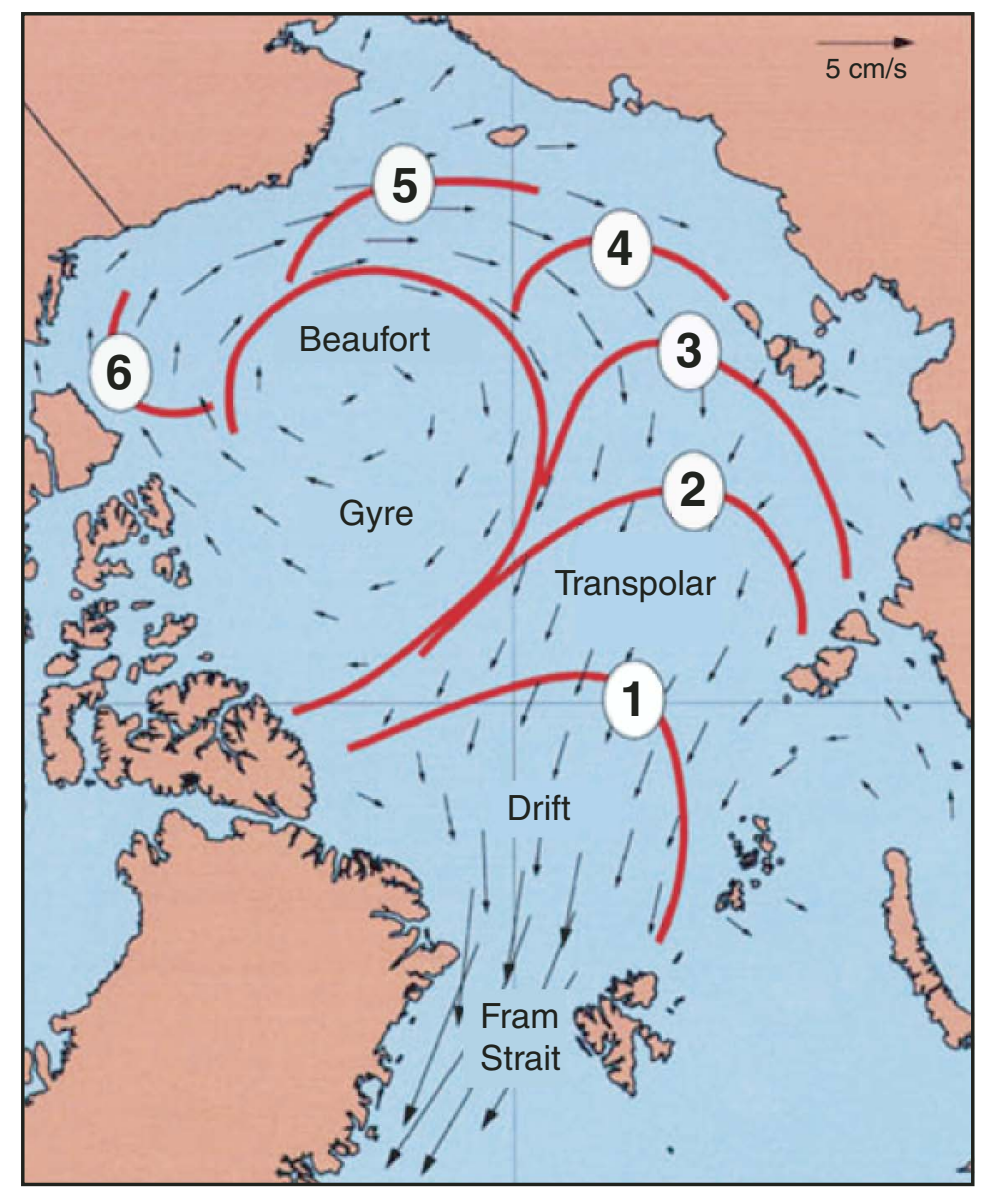


Figure F4. Photograph taken from one of the Expedition 302 helicopters of stationkeeping operations. The Sovetskiy Soyuz is shown at the top of the image breaking large ice floes, the Oden is in the middle of the image crushing mid-sized ice floes, and the Vidar Viking is in the lower section of the image maintaining station over the drill site.

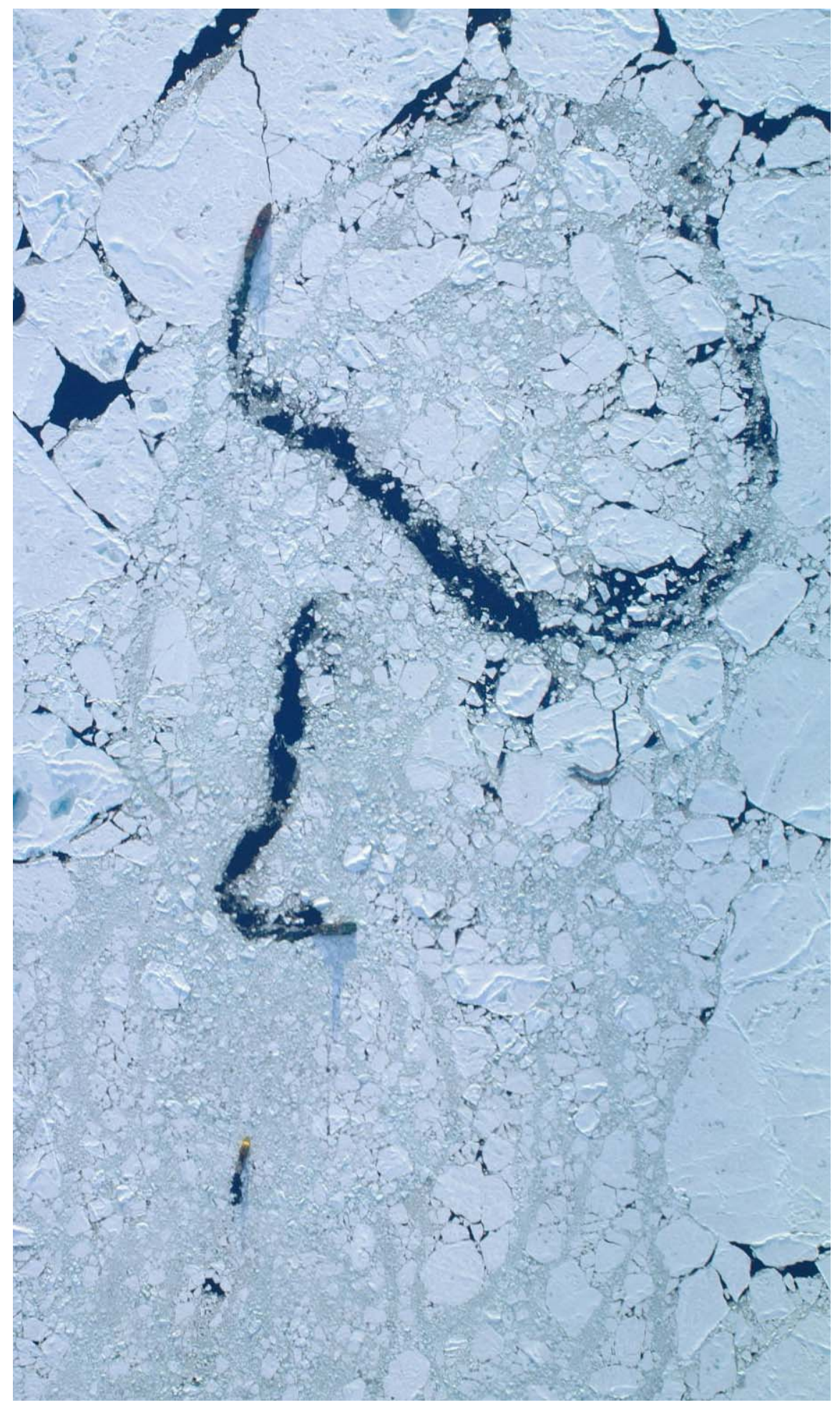


Figure F5. Core recovery summary diagram for all Expedition 302 holes. Black $=$ recovered core, white $=$ no recovery, and shaded $=$ washed intervals. Total recovery was $68.4 \%$. Hole M0004B was logged.

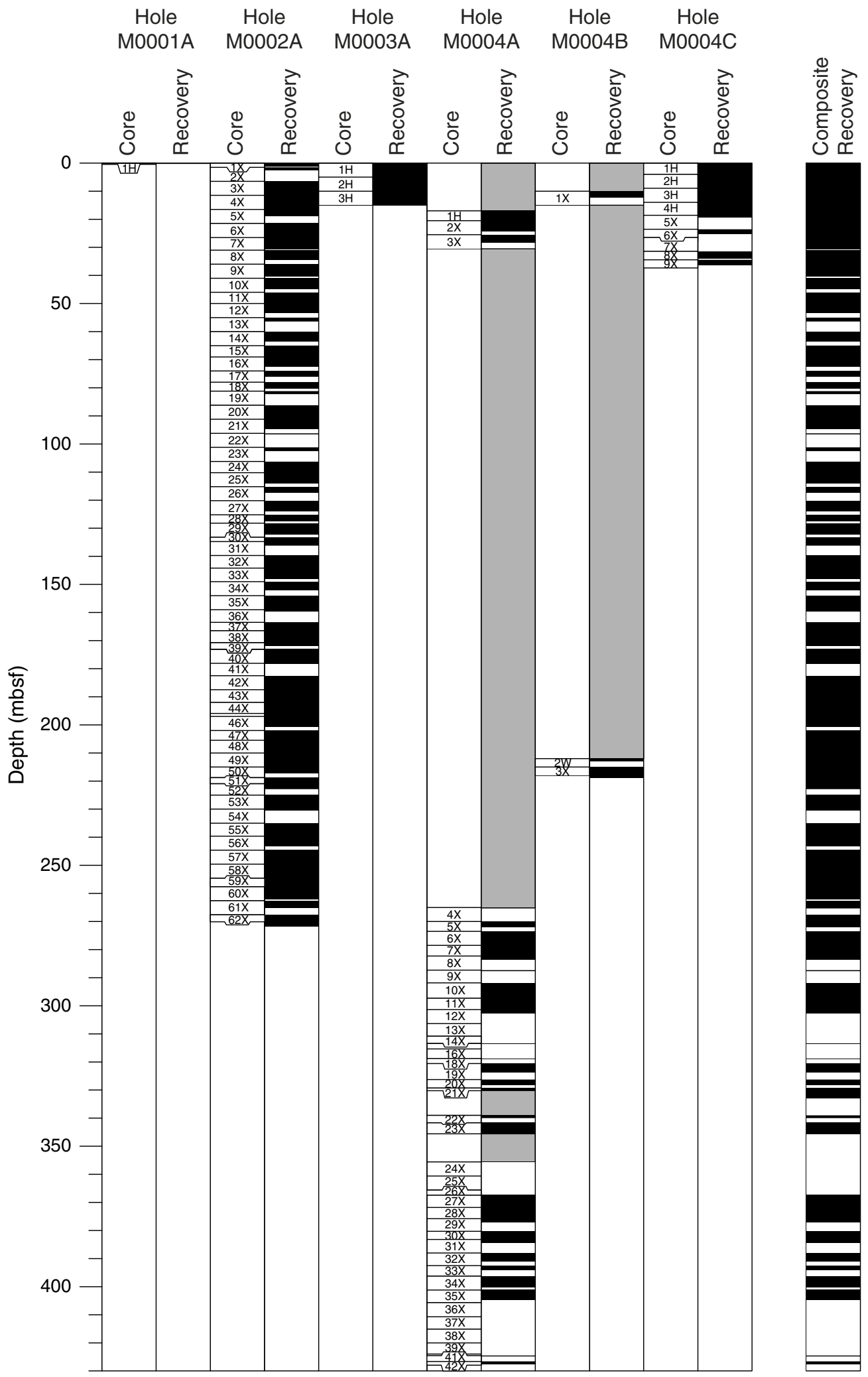


Figure F6. Lithostratigraphic column with age estimates of the Lomonosov Ridge sediments and basement. This is a compilation from all five boreholes. XRD = X-ray diffraction. (Continued on next page.)

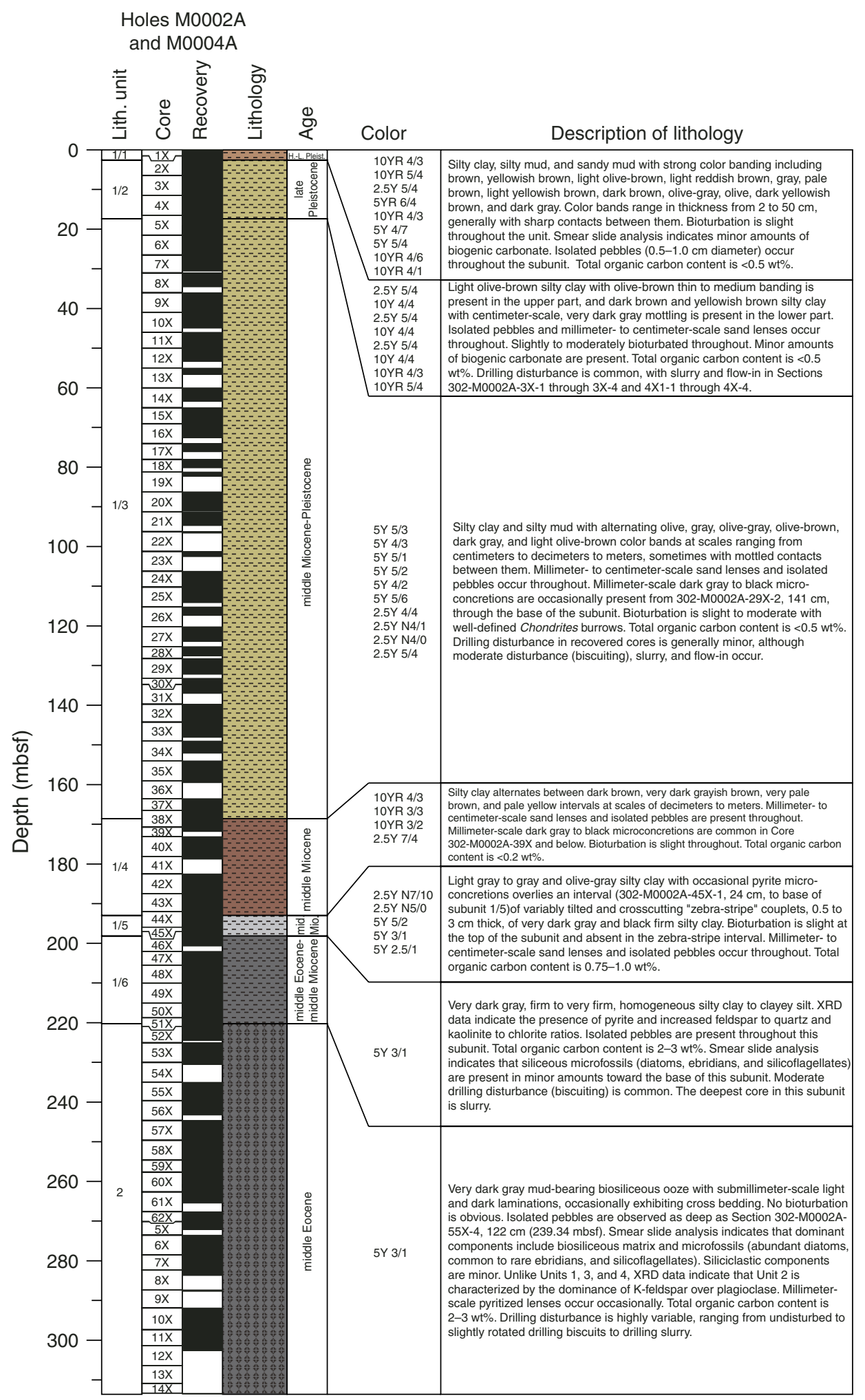


Figure F6 (continued).

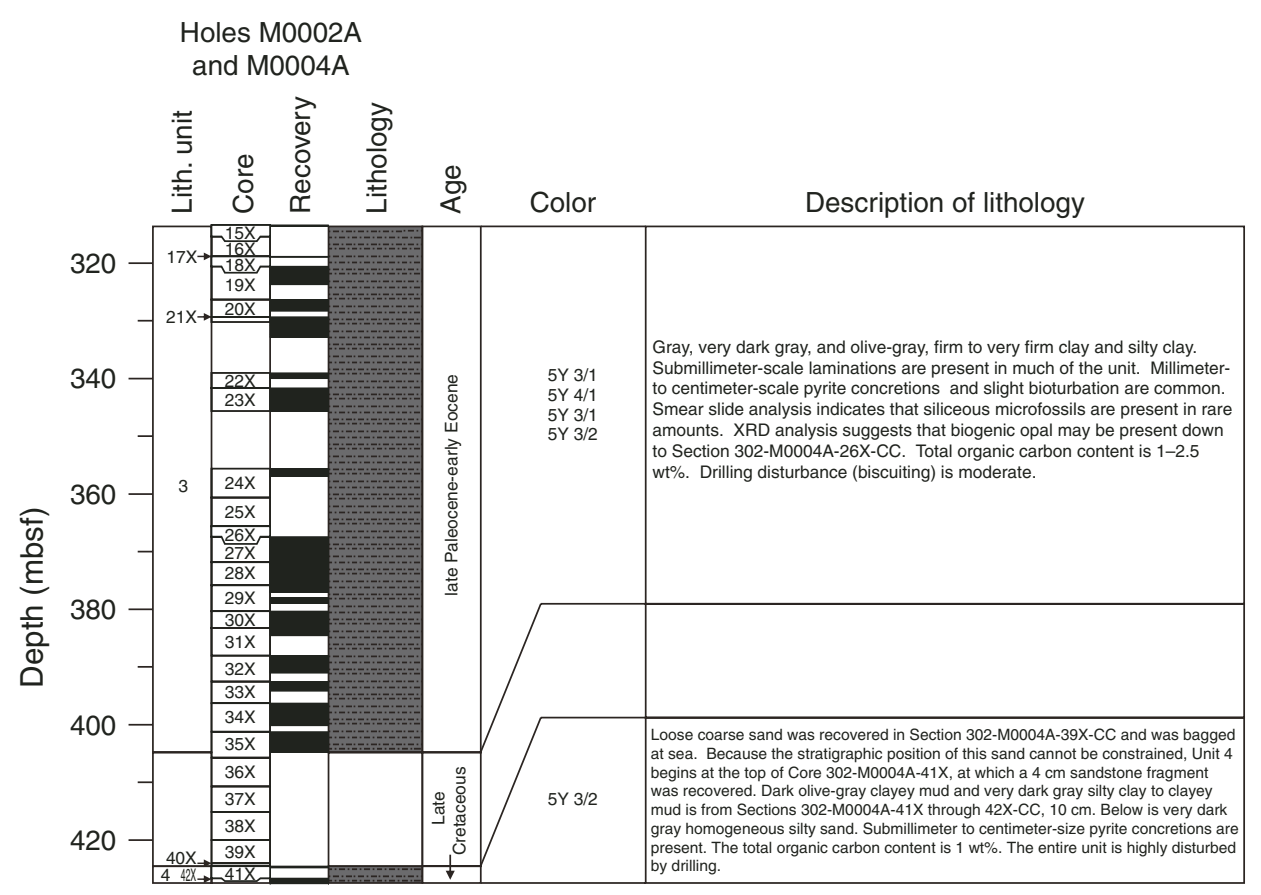


Figure F7. Multisensor core logger data plotted on a meters composite depth (mcd) scale and spliced together across all sites. GRA = gamma ray attenuation, NGR = natural gamma radiation. cps = counts per second. (Continued on next page.)

Sites M0002, M0003, and M0004
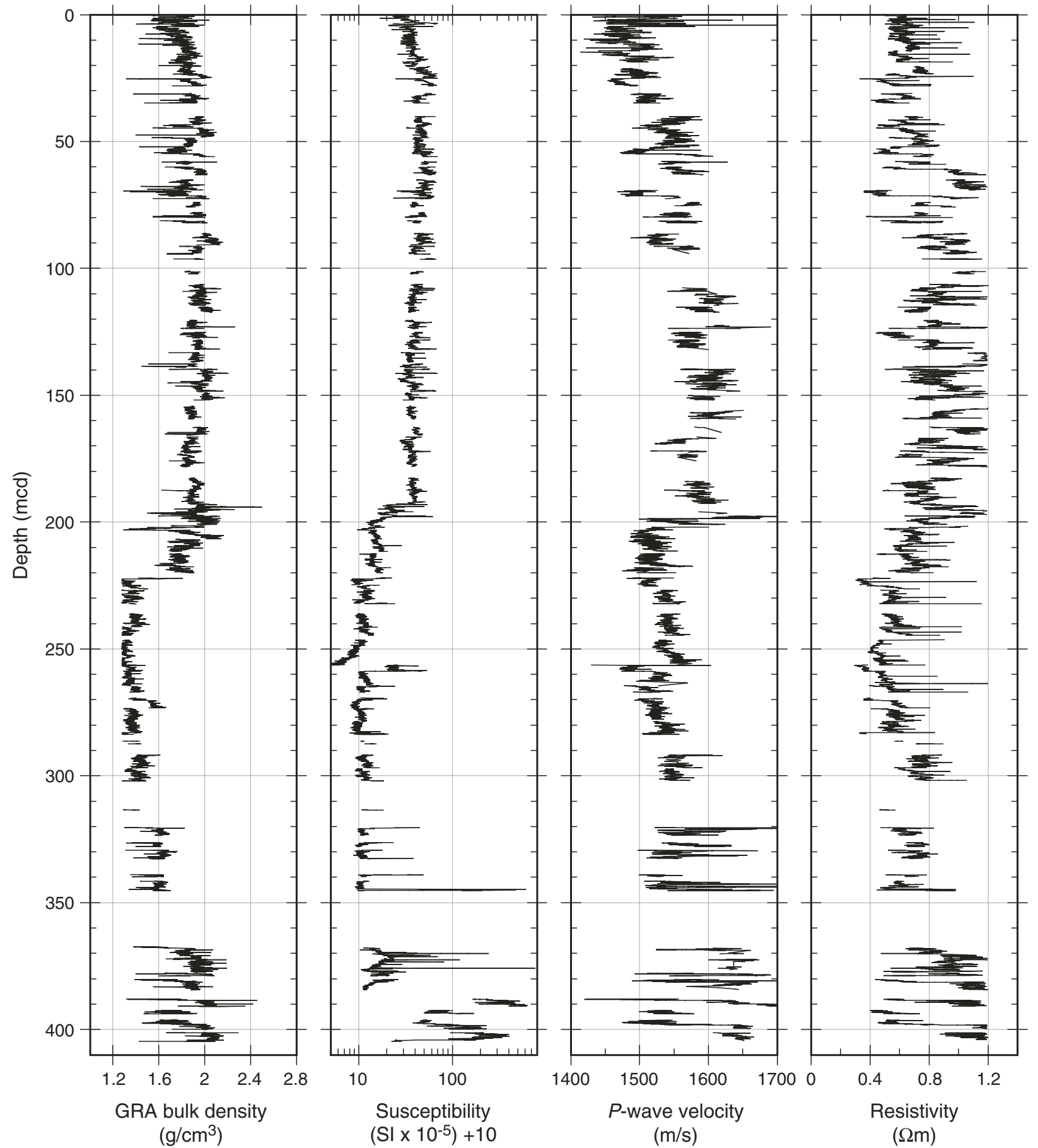
Figure F7 (continued).

Sites M0002, M0003, and M0004
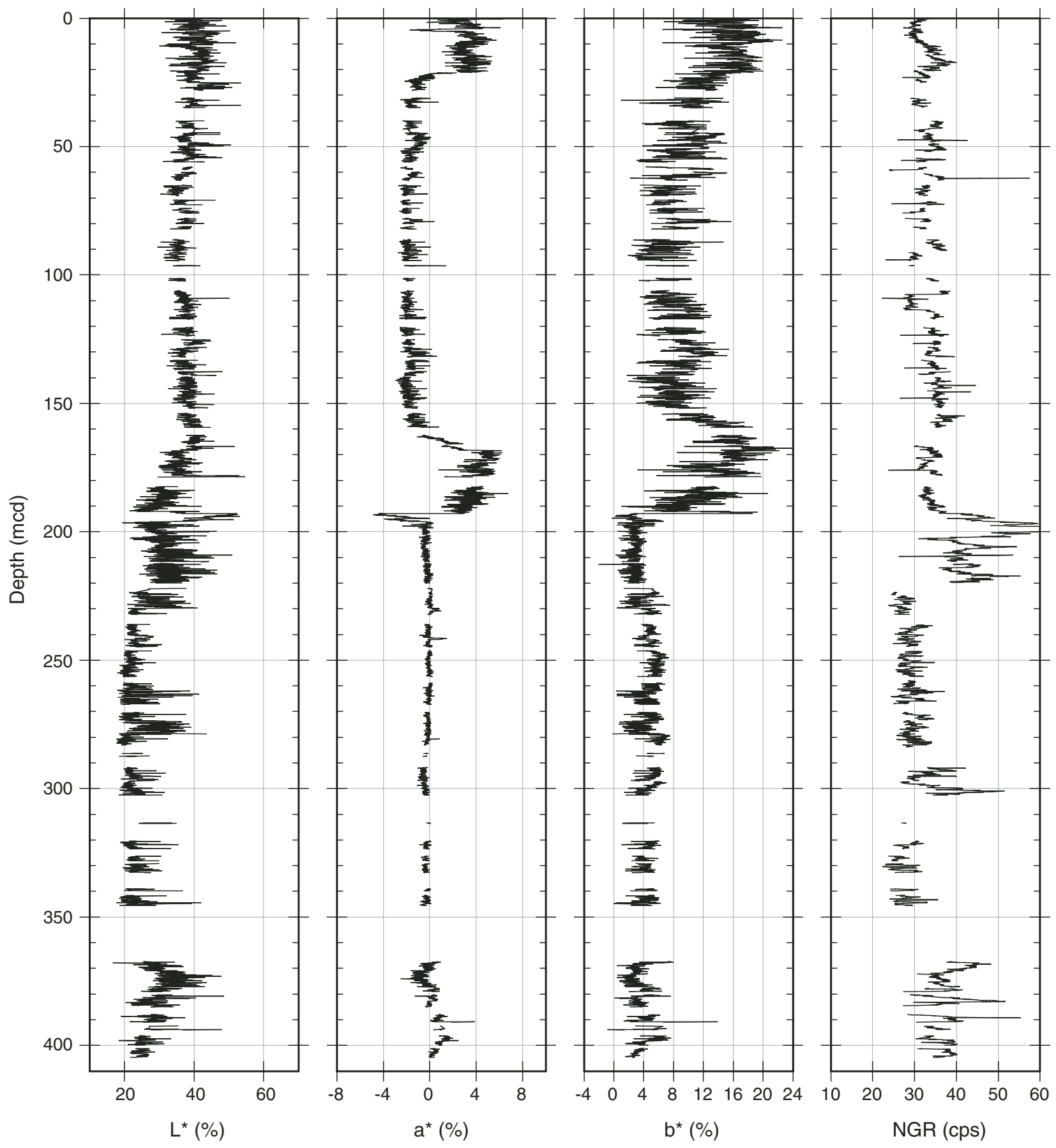
Figure F8. Multisensor core logger data for the upper 20 mcd showing all holes and the overlap achieved among them. GRA = gamma ray attenuation. (Continued on next page.)

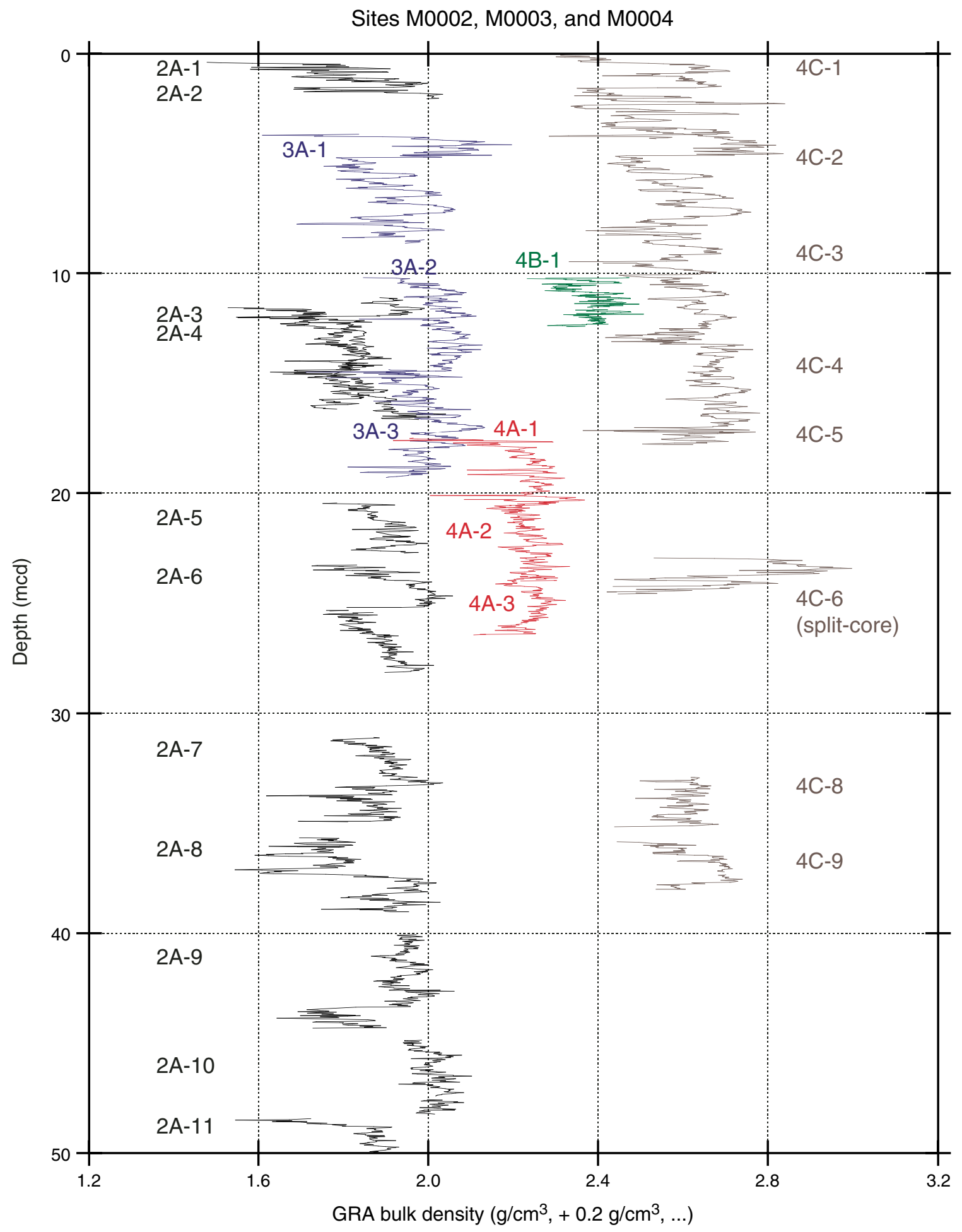


Figure F8 (continued).

Sites M0002, M0003, and M0004

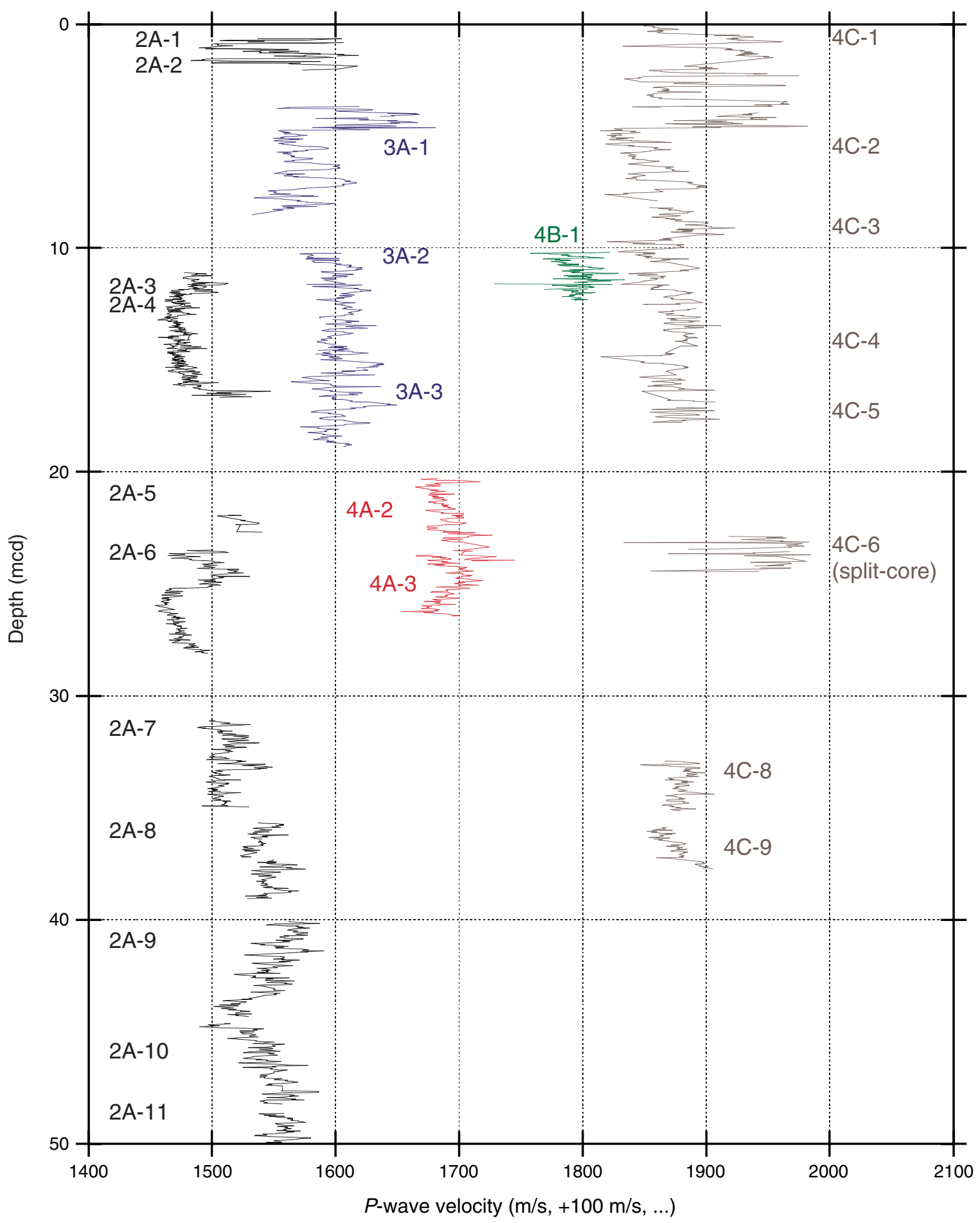


Figure F9. Compiled bulk density and shear strength data from offshore and onshore measurements. MSCL = multisensor core logger, $\mathrm{MAD}=$ moisture and density.

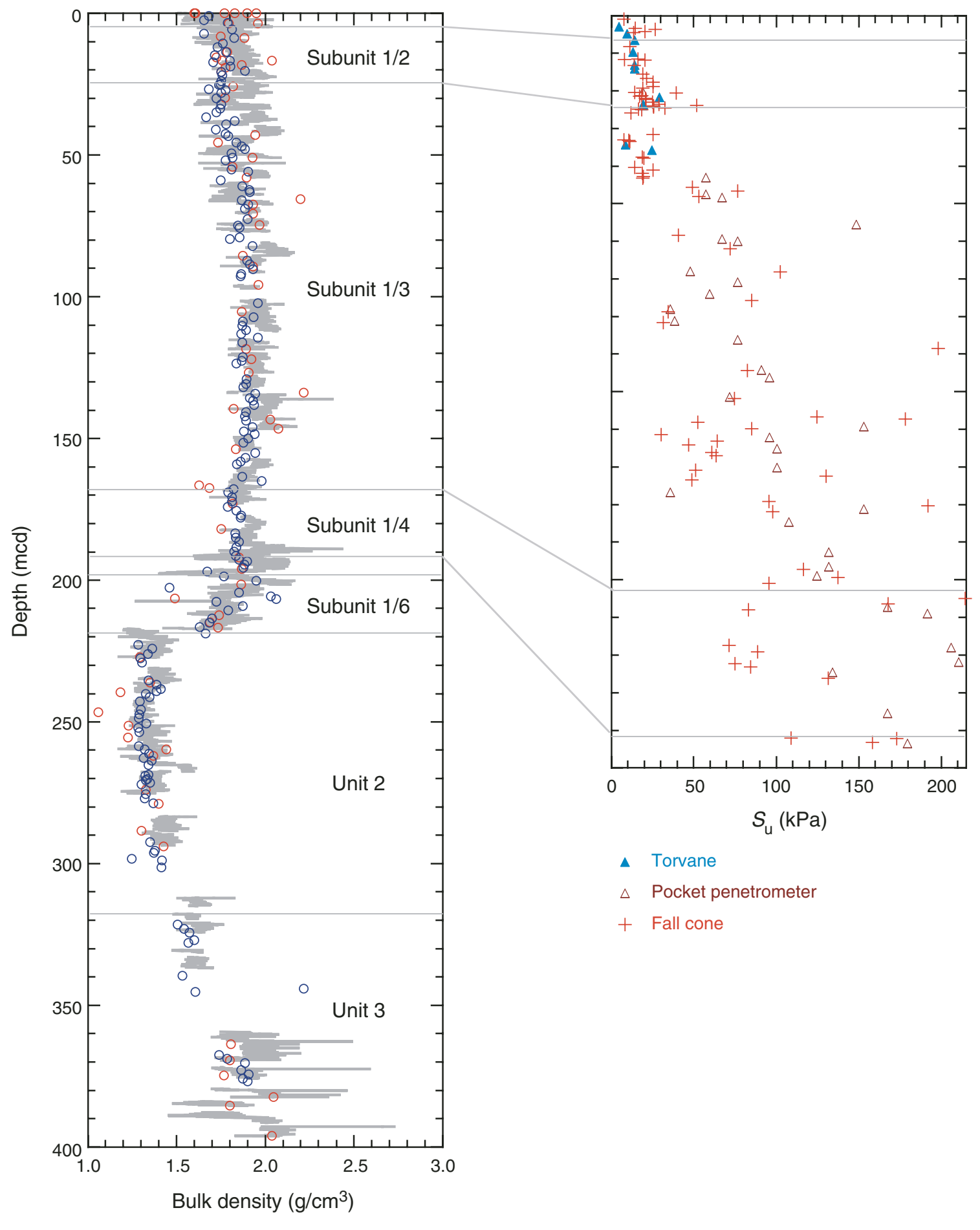

$\circ$ Offshore MAD
$\circ$ Onshore MAD 
Figure F10. Geochemical profiles measured in pore waters extracted from cores during the offshore phase of Expedition 302.
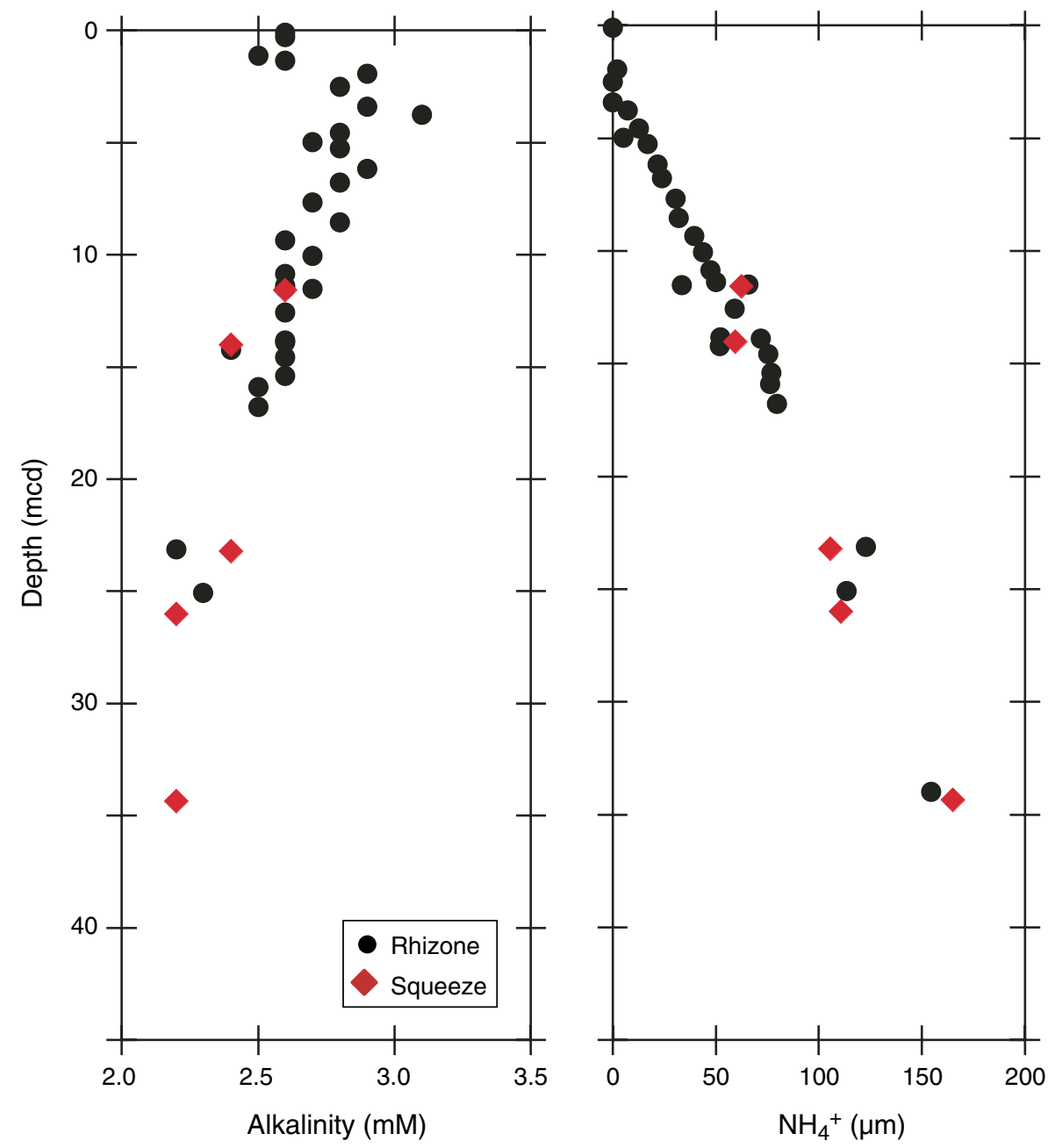
Table T1. Summary of core recovery.

\begin{tabular}{|c|c|c|c|}
\hline \multirow[b]{2}{*}{ Hole } & \multicolumn{2}{|c|}{ Length (m) } & \multirow{2}{*}{$\begin{array}{c}\text { Core recovery } \\
(\%)\end{array}$} \\
\hline & Cored & Recovered & \\
\hline M0002A & 271.69 & 213.15 & 78.5 \\
\hline M0003A & 15.00 & 14.85 & 99.0 \\
\hline M0004A & 157.59 & 78.41 & 49.8 \\
\hline M0004B & 11.00 & 7.31 & 66.5 \\
\hline M0004C & 40.19 & 25.34 & 63.1 \\
\hline Totals: & 495.47 & 339.06 & 68.4 \\
\hline
\end{tabular}

Table T2. Type and number of cores recovered.

\begin{tabular}{rccc}
\hline Hole & APC & XCB & Wash \\
\hline M0002A & 0 & 62 & \\
M0003A & 3 & 0 & \\
M0004A & 1 & 41 & \\
M0004B & 0 & 2 & 1 \\
M0004C & 4 & 5 & \\
Total number of cores: & \multicolumn{1}{c}{8} & 110 & 1 \\
Cored length (m): & 37.07 & 455.40 & 3 \\
Core recovered (m): & 36.86 & 301.2 & 1 \\
Core recovery (\%): & 99.4 & 66.1 & 33.3 \\
\hline
\end{tabular}

Note: $\mathrm{APC}=$ advanced piston corer, $\mathrm{XCB}=$ extended core barrel.

Table T3. Washed interval details.

\begin{tabular}{|c|c|c|c|}
\hline \multirow[b]{2}{*}{ Hole } & \multicolumn{2}{|c|}{ Depth (mbsf) } & \multirow{2}{*}{$\begin{array}{l}\text { Washed } \\
\text { interval }(\mathrm{m})\end{array}$} \\
\hline & Top & Base & \\
\hline M0004A & 0.00 & 17.00 & 17.00 \\
\hline M0004A & 30.50 & 265.00 & 234.50 \\
\hline M0004A & 330.18 & 339.00 & 8.82 \\
\hline \multirow[t]{2}{*}{ M0004A } & 345.60 & 355.60 & 10.00 \\
\hline & & Total: & 270.32 \\
\hline M0004B & 0 & 10 & 10 \\
\hline \multirow[t]{2}{*}{ M0004B } & 15 & 212 & 197 \\
\hline & & Total: & 207 \\
\hline
\end{tabular}

